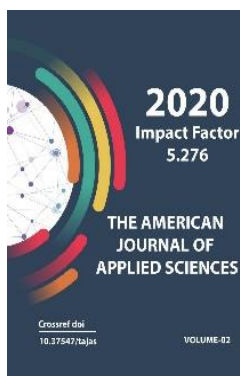

Copyright: Original content from this work may be used under the terms of the creative commons attributes 4.0 licence.

\section{People's Artist Of Uzbekistan Gavharkhonim Matyokubova}

Hulkar Hamroeva

Uzbek State Academy Of Choreography Senior Teacher, Candidate Of Philological Sciences, Tashkent City, Uzbekistan

Gulmira Qurbonova

UzDHA Art Studies Department, 3rd Year Student, Tashkent City, Uzbekistan

Sabina Hojieva

Tashkent State Law Student Of Academic Lyceum At The University, Tashkent City, Uzbekistan

\title{
ABSTRACT
}

This article is about the creative laboratory of the People's Artist of Uzbekistan, laureate of the Order of Labor Glory, well-known choreographer, art critic-ethnographer Gavharhonim Matyokubova.

\section{KEYWORDS}

Khorezm, "Avesto", history, legend, national identity, values, "Lazgi", cultural heritage, hafiz, dance school.

\section{INTRODUCTION}

In the Address of the President of the Republic of Uzbekistan Sh.M.Mirziyoev to the Oliy Majlis, it was emphasized that "further development of science in our country, education of our youth as owners of deep knowledge, high spirituality and culture" is extremely important. At the heart of any work of art and artistic creation is the perfection of man, his spiritual growth. Art and spirituality, art and literature purify the heart and soul, wash away its dust, lift the heart, give a world of pleasure, call for goodness and kindness.

At the 14th session of the UNESCO Intergovernmental Committee for the Safeguarding and Preservation of the Intangible Cultural Heritage in Bogota, Colombia, on 12 December 2019, the Uzbek national dance Lazgi was included in the Representative List of the Intangible Heritage of Humanity as an element of Uzbekistan's 
cultural heritage. The good news pleased not only Uzbeks, but all fans of Uzbek art around the world. This is the great performer, teacher, researcher and propagandist of the great "Lazgi" - a great connoisseur of Uzbek art and culture, whose ancient roots go back to the "Avesto", the image of a woman playing the chiltor, found in the walls of the Earth. People's Artist of Uzbekistan Gavharhonim Matyokubova's long-term hard work, research and creative thinking were highly appreciated.

\section{MATERIALS AND METHODS}

In the art world, not only creating a school, but also introducing any innovation, writing a pamphlet or manual requires real talent and perseverance, dedication, patience. The inclusion of Khorezm "Lazgi" in the UNESCO list was not easy, it is based on many years of research and selfless work of the master artist, because in all times, human society develops thanks to the progressive thinkers and implementers. Gavharhonim Matyokubova is a famous dancer who witnessed the creation of the ninth type of "Lazgi" - "yallali" by the great singer, People's Artist of Uzbekistan Komiljon Otaniyozov and was one of the first to perform it with great skill on foreign stages. His pamphlets "Ofatijon Lazgi" and "Lazgi" consistently analyze the process of enlightenment and cultural relations and values between generations, the process of disappearance and enrichment, development and internationalization. He cites historical examples that prove the invaluable role of art and culture in educating the younger generation to become full-fledged people, establishing and strengthening friendly relations between different nations. According to the author, the emergence of the dance "Lazgi" was a discovery of fire, which played an important role in human life. In particular, the natural process that led to this discovery is due to the geographical location, climate and weather conditions of the Orionvej region. The sacred book of Zoroastrianism, the Avesto, is the primary written source of information on this subject.

National dances reflect the spirit and nature, psyche and mentality of the nation. They cannot be imagined or studied in isolation from the customs and culture of the people. G.Matyokubova analyzes the long and recent history of "Lazgi" in conjunction with the games "Zimlak" and "Ashshadarozi" of the holiday "Red Flower" associated with ancient traditions.

"Representatives of different nationalities and ethnic groups, cultures and religions have lived in peace in Central Asia for many centuries. Hospitality, kindness, generosity of heart and true tolerance are always inherent in our people and form the basis of its mentality, "he said, referring to the intangible heritage of our great ancestors and the art of dance. After all, such qualities as sincerity, love, tolerance, openness, hospitality to the Uzbek people are a source of wisdom, which is fully reflected in the art of dance. Because national dances originated under certain conditions and they reflect different states of the human psyche, life and are the most influential means of art.

Each dance created by Gavharkhanim has its own imagery, unique beauty and magic, which appreciates the role and importance of art in strengthening the friendship and solidarity of different nations, enhancing creative cooperation between peoples and countries. "Khorezm, famous for its rich history and culture, has been inhabited by different nations and peoples for a long time. Many of them have come from other countries and settled in different ways," said Changak Lazgi, who has long held Khorezm as his homeland. , Persians who are Uzbeks "culture, customs and values.

The ancient roots of Lazgi embody the essence of the most delicate elements of the Khorezm dance school. "Masharaboz Lazgi", "Qayroq Lazgi”, "Dutor Lazgi”, "Surnay Lazgi”, "Saroy 
Lazgisi”, “Changak Lazgi”, "Khiva Lazgisi”, "Garmon Lazgisi", "Khorezm Lazgisi" 9 the magnificent work is an invaluable treasure that symbolizes how great and sacred the soil of our homeland is, how ancient and diverse our national dance art is.

In meetings with young people and journalists, in conversations with foreign experts and researchers, Gavharkhanim praised the real devotees of "Lazgi" Sharip Dusboboev, Honored Artist of Uzbekistan O.Gayibova, K.Kutlimurodov, People's Artist of Uzbekistan Bikajon Rahimova, Sultan Otaniyozov, Masharif Tukay, Buvajon Qayrak, M .Kharratov, Sora bola, H.Boltaev, O.Kushmonov, Saodat mercury, G.Abdullaeva, G.Mirzaeva, R.Sapoeva, Sh.Toganov, Davlat surnaychi, M.Alieva, Rajab lak-lak, Qodir bola, Z. He emphasizes the merits of such famous artists as Latipov, H. Ollamov. Anash Khalfa, who founded a school in Khorezm art, mentions the famous hafiz Komiljon Otaniyozov, Roviya Otajonova, Sora Olloberganova, Oliya Otamuradova one by one, and highly respects their selfless work and skills, their legacy.

People's Artist of Uzbekistan, famous artist G.Matyokubova in her pamphlets describes the history of "Lazgi", the stages of its formation and its aspects related to the "Avesto", the features that combine national values and traditions, the mythological roots of 9 "Lazgi", close and different proves its aspects on the basis of historical reality, creates a perfect portrait of the dance through the myths, legends associated with them, the lapars that pass from language to language over the centuries. In all his researches, the teacher considers the values of the people associated with the art of dance as an ethnographer-art critic, an experienced pedagogue, compares important facts, views and opinions on the history of the Khorezm dance school, in particular, "Lazgi", boldly measures them in terms of time and thought. Lazgi's international prestige justifies the continuation of the traditions of such teachers as Anajon Sobirova, popularly known as Anash the Lame, and the unique hafiz Komiljon Otaniyozov. Based on real facts, it tries to fully reflect the realities of the past, to accurately express the historical truth, the spirit of the period and the region associated with the Khorezm Dance School.

\section{DISCUSSIONS AND RESULTS}

There is hardly a person like Gavhar Opad who knows the history of his country well, loves it and tells it like a magic fairy tale. Benazir's teacher Komiljon Otaniyozov's loving and responsible promotion of his multifaceted work is an example. The wisdom in his eyes, the thirst for knowledge, the love of the art world have shifted to dances. The nurse works long on each new dance. The harmony of the inner state, movements and symbols, colors and tones does not cease to work until it touches the heart. He learned to love and cherish music and dance as a divine miracle, to bring up young people with love from Komiljon Hafiz.

The roots of the ancient Khorezm, the subtlety and in genuity of the ancient Khorezm are reflected in the dances created by Gavharkhanim, as the theme of the legendary history of this legendary land is always at the peak of her creativity. Of course, this process requires serious research: he studied in depth the Khorezm khanates, the culture and art of that period, the history of clothing and jewelry, folk customs, struggles and aspirations, lifestyle. G.Matyakubova delights the audience by expressing her love for the history of the Motherland, her inner experiences in dances, and encourages her to think, to understand the essence of the contradictions of life. Satisfaction with one's destiny, joys, sorrows that have been a stone in one's heart for years, what one has found, what one has lost, what burns one's heart like fire, become a dance. 
He draws strength from the classical literature of Khorezm and finds the necessary lines for his unique dances from the ghazals of Khorezm, Ogahi, Feruz. With his charming art he gives grace to the circles, delights the hearts, creates beauty. Gavharkhanim always strives for the purity of the Uzbek national dance art, for the restoration and preservation of the lost dances. He cares that the roots of national art will always be strong. His dances, which amaze the world, combine history, romantic pleasure and vitality, reflecting the spirit of the past and the present.

Khorezmian dances are so lively, bright and charming that they captivate the audience. Each of Gavharkhanim's works is a unique event in the development of national dance. He collected, summed up, polished and revived the disappearing Lazgi movements, which were scattered in the memory of the people like pearls. To cite just one example: in May 1997, the 2,500th anniversary of ancient and eternally young Khiva was celebrated in Paris, France. On the occasion of this anniversary, Gavharhonim Matyokubova, People's Artist of Uzbekistan, a well-known representative of the Khorezm Dance School, a highly talented dancer and choreographer, created the composition "Legend of Lazgi". It connects the existing 9 "Lazgi" and reveals the stages of gradual development of Uzbek dance.

The composition "Legend of Lezgi" was staged as follows: In the middle of the Holy Tower there is a fire. The dancing girls are standing around the fire with a lighted candle in their hands with an elegant veil over their faces. The traditional rez of "Lazgi" begins. On the right side of the stage, the narrator appears and begins his story. And the creation of man tells the story of the soul entering the body with a celestial melody, first to the fingers, then to the wrists and shoulders, and finally to the head. During the story, he spoke about eight "Lazgi" and its ninth type, "Yallali lazgi" created by the great hafiz Komiljon Otaniyazov. "After the discovery of Komiljon hafiz, this melody became eternal, an eternal song of love and beauty," he concluded. These words are said while the rez part of the Lezgi melody is being played. At that moment, a soulful dancer emerges from the fire in the middle in the form of music. The hands seem to be torn to pieces, trembling, trembling, slowly rising with dance movements. With a sad expression on his face, the "soul" slowly begins to spin. He goes to the girl holding the candle and stops, and touches his finger to the girl, who is stiff as a statue. The trembling girl slowly begins to shake. Now "John" runs to another girl. He touches her too. In this case, he goes to the 20 girls on stage one by one and repeats this action. It is as if the girls are alive and the dancers slowly place the candle in their hands on the ground. They rotate where they open the curtains on their faces, and one hand stiffens at the top. The main part of the melody "Lazgi" begins. Soz makes a moan. The hands are frozen above. Nola continues again, turning into a fig. The fingers begin to move slowly. Then the paws, wrists, shoulders move forward - then. He breathes life into his body, shakes his head, as if resurrected.

Next to the girl in the middle, who looks like "John", there is a young man who is playing hard. They're in a game. The circle is divided into two sides, applauding their dancer and dancer and accompanying them with dance moves appropriate to the melody. Now the dancers throw one foot forward, one foot back, and begin to circle around the boy and girl in the middle in a Khorezmian foot style. At the end of the dance, everyone claps their hands and suddenly the dancer fires in the middle, and the girls finish the dance with candles in their hands.

\section{CONCLUSION}

Surprised participants - guests from different countries, historians, scientists, journalists, artloving French people, representatives of the diplomatic corps - long applauded 
Gavharkhanim, the beautiful dancers who performed her legendary dance ... The article was written by the talented poet Jumanazar Yusupov We wanted to end with the lines:

Don't say dance is a game, there is no pain,

If you fall, it's hard to get out of its depths.

I can barely get rid of a thousand ways,

From the unbroken chains of "Lazgi"

\section{REFERENCES}

1. Meeting of the President of the Republic of Uzbekistan Sh.M.Mirziyoev with creative intellectuals UzA, August 3, 2017.

2. Karimova R. Uzbek dances. Cholpon, T.2003. 5-b.

3. 3.O'zME, T.2008. Volume 9.615-b.

4. Toxtasimov Sh. Hamroeva H. "The winner is his invention ..." "Gulistan", issue 2. T., 2020y.

5. A.Navoiy, Sab'ai planet, T. 1998. 258-b.

6. Dictionary of Navoi works, T., 1972., 30 p.

7. Sadokov L.R. "Musical archeology of ancient and medieval Central Asia: percussion instruments". M.1996.s.35.

8. Kobilniyozov J. Khorezm folk songs and games. T., 1975. 17-p.

9. Akbarov I. Dictionary of music. "Teacher" T., 1997

10. G.Matyoqubova Lazgi.Tashkent, 2020.

11. Toxtasimov Sh. Xamraeva X. Murodova M. Uzbek natsionalnoe tantsevalnoe art: from stanovleniya to povbsheniyu. ACADEMY. Russia. 2019. №12. S.56-57-58. 